\title{
Natural conjugated linoleic acid enriched lamb meat fat modifies tissue fatty acid profile and increases n-3 HUFA score in obese Zucker rats
}

\author{
G. Carta ${ }^{1}$, E. Murru ${ }^{1}$, C. Manca ${ }^{1}$, A. Abolghasemi ${ }^{1}$, A. Serra ${ }^{2}$, M. Mele ${ }^{2}$ and S. Banni ${ }^{1}$ \\ ${ }^{1}$ Department of Biomedical Sciences, University of Cagliari, Cagliari, Italy and ${ }^{2}$ Department of Agriculture, Food and \\ Environment, University of Pisa, Pisa, Italy.
}

\begin{abstract}
Animal fat, are often associated with diet-related health problems such as obesity, diabetes, cardiovascular disease (CVD), and tumours. However, ruminant's fat can be modified according to animal diet, and fat from light lambs (namely lambs fed exclusively mother's milk) is particularly rich in conjugated linoleic acid (CLA) and $\boldsymbol{\checkmark}$-linolenic acid (ALA) ${ }^{(1)}$. We have shown that in hypercholesteraemic subjects food enriched with CLA and ALA is able to significantly increase plasma n-3 HUFA score ${ }^{(2)}$, a biomarker of n-3 fatty acid in tissue. This is calculated as the percentage of n-3 highly unsaturated fatty acid (HUFA $\geq 20$ carbons and $\geq 3$ double bonds) in the total PUFA pool mainly incorporated into phospholipids, and potentially precursors of biological active eicosanoids and docosahexaenoids ${ }^{(3)}$. Therefore, an enhanced n-3 HUFA score reflects an increase of n-3/n-6 HUFA ratio in tissues, which has been associated with several health benefits ${ }^{(4)}$.

To compare the activity of different lamb meat fats with dissimilar fatty acid profile on lipid metabolism, by GC and HPLC analyses $^{(2)}$, Zucker rats (n=6/group), an animal model of obesity, were fed for four weeks with four diets, three containing lamb meat fat: A) enriched in CLA; B) enriched in ALA; C) relatively low in both; and fourth diet (D) based on a mixture of olive and corn oils fat.

Our results showed that body and liver weights were not influenced by dietary fat sources. CLA and ALA were incorporated in most tissues following their dietary content; EPA and DHA incorporation was found increased in tissues according to ALA in the diets and largely influenced by dietary CLA. In addition, our data showed an increase in n-3 HUFA score in liver, subcutaneous (SAT) and visceral adipose tissue (VAT), and plasma of rats fed with animal fat with respect to the vegetable one. As expected, the highest increases were found in tissues of rats fed A and B diets, while in hypothalamus and heart n-3 HUFA score increased significantly only in those rats fed with A diet (Table 1). In particular, n-3 HUFA score significantly correlated to incorporated CLA $\left(\mathrm{r}=0,9022 \mathrm{P}^{* * *}\right.$ and $\left.\mathrm{r}=0.855 \mathrm{P}^{* * *}\right)$, and ALA $\left(\mathrm{r}=0,613 \mathrm{P}^{* *}\right.$ and $\left.\mathrm{r}=0.544 \mathrm{P}^{* *}\right)$ in plasma and liver respectively; while correlated only with CLA in heart $\left(\mathrm{r}=0.549 \mathrm{P}^{* *}\right)$, VAT $\left(\mathrm{r}=0.613 \mathrm{P}^{* *}\right)$ and SAT $\left(\mathrm{r}=0.816 \mathrm{P}^{* * *}\right)$, and in hypothalamus only with ALA $(\mathrm{r}=0.632 \mathrm{P} *)$. (Person correlation $* \mathrm{P}<0.05 ; * * \mathrm{P}<0.01$ : *** $\mathrm{P}<0.001)$.
\end{abstract}

Table 1. n-3 HUFA score in rat tissues. Different letters indicate significant differences among diets, one-way ANOVA Tukey's post hoc multiple comparisons test $(\mathrm{P}<0,05)$

\begin{tabular}{|c|c|c|c|c|c|c|c|c|c|c|c|c|}
\hline \multirow[b]{2}{*}{ diets } & \multicolumn{2}{|l|}{$\underline{\text { Liver }}$} & \multicolumn{2}{|l|}{ Heart } & \multicolumn{2}{|l|}{ VAT } & \multicolumn{2}{|l|}{$\underline{\text { SAT }}$} & \multicolumn{2}{|c|}{$\underline{\text { Plasma }}$} & \multicolumn{2}{|c|}{ Hypothalamus } \\
\hline & $\overline{\text { mean }}$ & $\pm \mathrm{SE}$ & mean & $\pm \mathrm{SE}$ & $\overline{\text { mean }}$ & $\pm \mathrm{SE}$ & $\overline{\text { mean }}$ & $\pm \mathrm{SE}$ & $\overline{\text { mean }}$ & $\pm \mathrm{SE}$ & mean & $\pm \mathrm{SE}$ \\
\hline $\mathbf{A}$ & 32,0 & $0,83^{\mathrm{a}}$ & 34,6 & $0,26^{\mathrm{a}}$ & 22,8 & $2,41^{\mathrm{a}}$ & 23,7 & $1,03^{\mathrm{a}}$ & 22,8 & $0,91^{\mathrm{a}}$ & 49,8 & $0,86^{\mathrm{a}}$ \\
\hline B & 30,3 & $0,59^{\mathrm{a}}$ & 31,9 & $1,06^{\mathrm{a}}$ & 23,5 & $0,81^{\mathrm{a}}$ & 22,2 & $0,95^{\mathrm{a}}$ & 21,2 & $0,72^{\mathrm{b}}$ & 48,9 & $0,11^{\mathrm{a}}$ \\
\hline $\mathbf{C}$ & 28,1 & $0,19^{\mathrm{b}}$ & 32,0 & $1,10^{\mathrm{a}}$ & 19,3 & $0,97^{\mathrm{a}}$ & 18,9 & $0,67^{\mathrm{b}}$ & 20,2 & $0,33^{\mathrm{bc}}$ & 48,3 & $0,18^{\mathrm{a}}$ \\
\hline D & 24,4 & $0,23 \mathrm{c}$ & 25,1 & $0,69^{\mathrm{b}}$ & 14,2 & $1,07^{\mathrm{b}}$ & 12,8 & $0,68^{\mathrm{c}}$ & 16,2 & $0,02^{\mathrm{c}}$ & 47,6 & $0,22^{\mathrm{b}}$ \\
\hline
\end{tabular}

We may conclude that animal fat nutritional values were strongly influenced by animal dietary regimen and the subsequent increase of dietary CLA and ALA significantly increased the tissue n-3 HUFA score, which has been shown in humans to be inversely correlated to CVD. Therefore, rather than focus the attention on animal fat, it should be considered the dietary fat profile irrespective of their origin.

1. Serra A, Mele M, La Comba F et al. (2009) Meat Sci 81, 396-404.

2. Pintus S, Murru E, Carta G et al. (2013) Br J Nutr 109, 1453-1462.

3. Stark KD (2008) Lipids 43(1), 45-53.

4. Murru E, Banni S. and Carta G (2013) BioMed Res Int DOI 101155/2013/965417, 1-13. 